\title{
ANALYSIS OF DEMAND FOR ECONOMIC SPECIALTIES IN UKRAINE IN THE CONTEXT OF WORLD EDUCATIONAL INTEGRATION
}

\author{
Maryna Kovbatiuk ${ }^{1}$ \\ Vladyslava Shevchuk ${ }^{2}$
}

DOI: https://doi.org/10.30525/978-9934-588-39-6-48

According to the Decree of the Cabinet of Ministers of Ukraine No. 266 «On Approving the List of Fields of Knowledge and Specialties for which Higher Education Applicants Are Prepared» dated April 29, 2015 [1], four are the economic fields in Ukraine, which with corresponding specialties are shown in Figure 1.

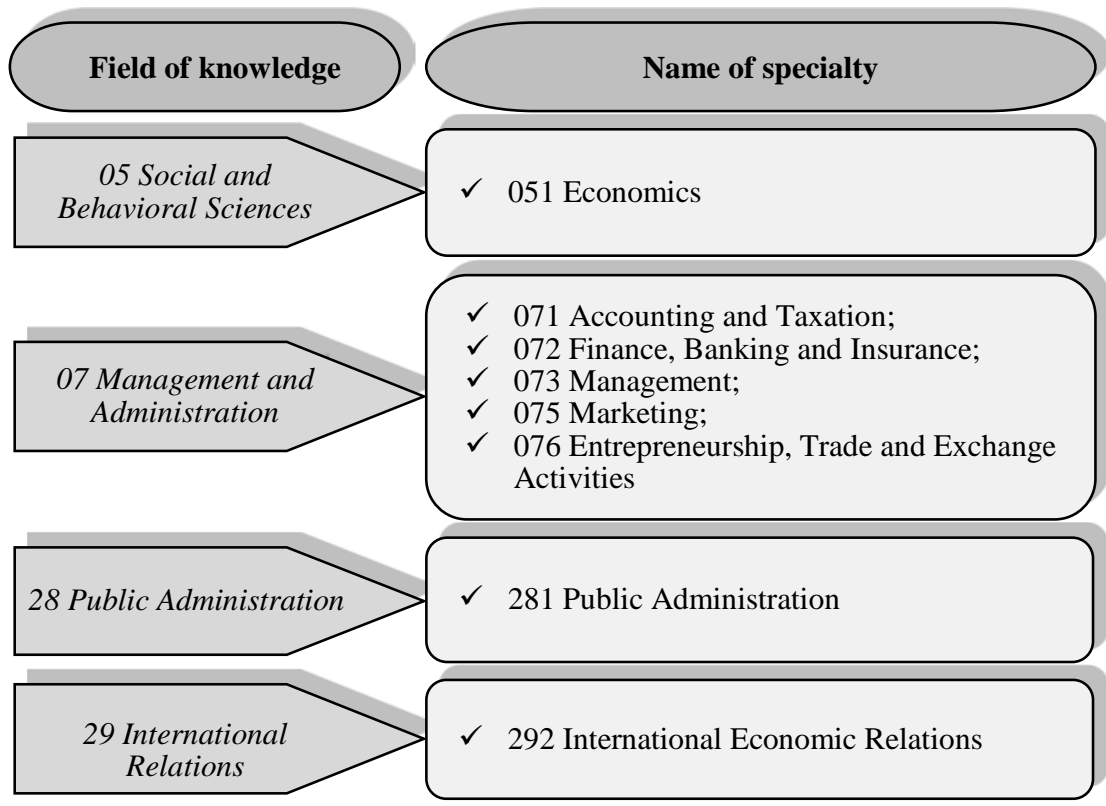

Figure 1. The list of economic branches of knowledge and specialties by which the students of higher education are trained

Source: compiled by authors [1]

\footnotetext{
${ }^{1}$ State University of Infrastructure and Technologies, Ukraine

${ }^{2}$ State University of Infrastructure and Technologies, Ukraine
} 
The data in Table 1 reflect the number of students in universities III-IV accreditation levels at the beginning of the academic year, by educational levels and branches of knowledge, according to the 2015 list.

Table 1

Number of students in universities III-IV accreditation levels by economic branches of knowledge at the beginning of the academic year, 2016-2018 [2]

\begin{tabular}{|c|c|c|c|c|c|c|c|}
\hline \multirow{3}{*}{$\begin{array}{c}\text { Higher } \\
\text { education } \\
\text { degree }\end{array}$} & \multirow{3}{*}{$\begin{array}{l}\text { Field of } \\
\text { knowledge }\end{array}$} & \multicolumn{6}{|c|}{$\begin{array}{c}\text { Number of students in universities } \\
\text { III-IV accreditation levels }\end{array}$} \\
\hline & & \multicolumn{2}{|c|}{ 2016/17 } & \multicolumn{2}{|c|}{$2017 / 18$} & \multicolumn{2}{|c|}{ deviation } \\
\hline & & persons & $\%$ & persons & $\%$ & $+/-$ & $\%$ \\
\hline \multirow{4}{*}{ Bachelor } & $\begin{array}{l}05 \text { Social and } \\
\text { Behavioral } \\
\text { Sciences }\end{array}$ & 14213 & 17,9 & 38112 & 16,67 & 23899 & 268,1 \\
\hline & $\begin{array}{l}\text { 07 Manage- } \\
\text { ment and } \\
\text { Administration }\end{array}$ & 26826 & 33,76 & 78140 & 34,19 & 51314 & 291,3 \\
\hline & $\begin{array}{l}28 \text { Public } \\
\text { Administration }\end{array}$ & - & - & 3070 & 1,35 & 3070 & - \\
\hline & $\begin{array}{l}29 \text { International } \\
\text { Relations } \\
\end{array}$ & - & - & 11026 & 4,82 & 11026 & - \\
\hline \multicolumn{2}{|l|}{ At once } & 41039 & 51,62 & 130348 & 57,03 & 89309 & 317,62 \\
\hline \multirow{4}{*}{ Master } & \begin{tabular}{|l|}
05 Social and \\
Behavioral \\
Sciences
\end{tabular} & 9955 & 12,53 & 19074 & 8,35 & 9119 & 191,6 \\
\hline & $\begin{array}{l}07 \text { Manage- } \\
\text { ment and } \\
\text { Administration } \\
\end{array}$ & 28468 & 35,82 & 64675 & 28,31 & 36207 & 227,2 \\
\hline & $\begin{array}{l}28 \text { Public } \\
\text { Administration } \\
\end{array}$ & - & - & 10301 & 4,50 & 10301 & - \\
\hline & $\begin{array}{l}\text { 29 International } \\
\text { Relations }\end{array}$ & - & - & 4148 & 1,81 & 4148 & - \\
\hline \multicolumn{2}{|r|}{ At once } & 38423 & 48,38 & 98198 & 42,97 & 59775 & 255,57 \\
\hline \multicolumn{2}{|c|}{ At all } & 79462 & 100 & 228546 & 100 & $\mathrm{x}$ & $\mathrm{x}$ \\
\hline
\end{tabular}

As we can see, there is a steady demand for higher education in economic specialties over the two academic years. Since in the 2016/17 academic year most students studied in the areas of preparation, there is a significant difference of absolute indicators for the two academic years - 2.5-3 times. At the same time, relative indicators show strong trends. 
If we consider the structure of the number of students in all branches of knowledge, the share of the number of students studying in economic specialties, according to the data $2017 / 18$ academic year is $21.16 \%$. This is slightly more than a fifth of everyone who wants to get a college degree.

The desire to get an economical higher education is explained by the steady demand for economic specialties from the business side, with almost all graduates getting jobs.

In the structure of the number of students in the Higher Education Levels III-IV levels of accreditation in the economic branches of knowledge of higher education degrees «Bachelor» and «Master» the greatest share is the branch of knowledge 07 «Management and Administration» - 59.95\% and $65.86 \%$ respectively (Figure 2 ).

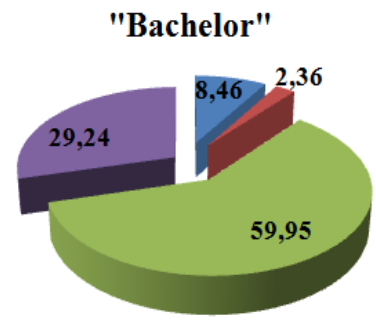

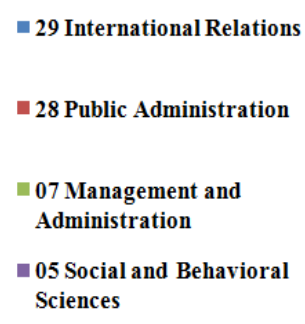

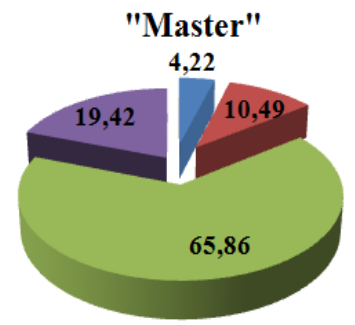
Figure 2. Structure of the number of students in the Higher Education Level III-IV accreditation levels in the economic branches of higher education «Bachelor» and «Master» degrees in the 2017/18 academic year, $\%$

Source: compiled by authors [2]

First of all, this is because this area of expertise has five specialties. In the second place - specialty 051 «Economics», its share is $29.24 \%$ and $19.42 \%$ respectively. Specialties such as 281 «Public Administration» and 292 «International Economic Relations» are gaining popularity.

In our opinion, it is the specialty 292 «International Economic Relations» that is the most promising. Modern globalization processes that are taking place in the world require skilled personnel of this area of knowledge. This is confirmed by the data in Figure 3. As we can see, it is the field of knowledge «International Relations» that is in greatest demand in Ukraine. In addition, according to the introduction company 2019 to enter the budget was the most difficult in the specialty of this industry - a passing score on them is more than 190 points. The entry for a wide bachelor's competition for full-time study is intended. 


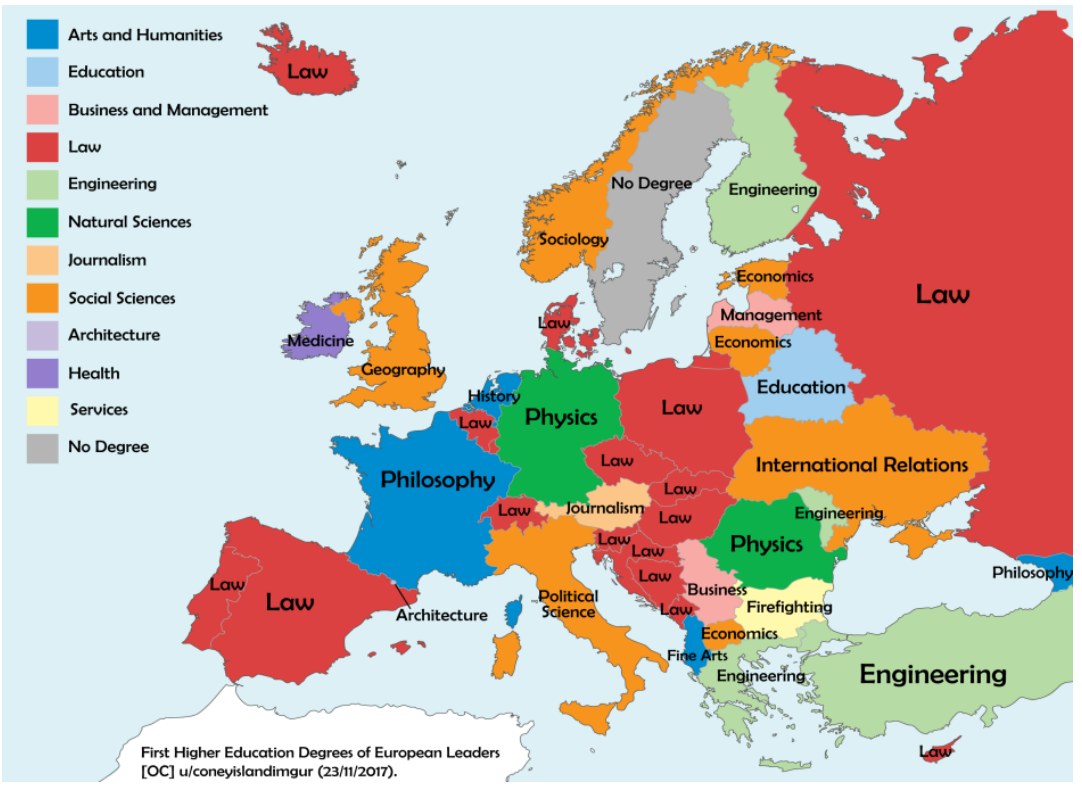

Figure 3. Map of the popularity of the first degrees of higher education in Europe [3]

The top 10 specialties with the highest passing scores in 2019 are listed in Table 2.

Table 2

Top 10 specialties with highest passing scores in 2019 [4]

\begin{tabular}{||c||l|c||c||l||c||}
\hline № & Specialties & Points & № & Specialties & Points \\
\hline \hline 1 & International Law Relations, & 194,25 & 6 & Journalism & 188,75 \\
2 & $\begin{array}{l}\text { International } \\
\text { Public Communications and } \\
\text { Regional Studies }\end{array}$ & 194,004 & 7 & $\begin{array}{l}\text { Medical } \\
\text { Psychology }\end{array}$ & 186,9 \\
\hline 3 & $\begin{array}{l}\text { International Economic } \\
\text { Relations }\end{array}$ & 190,84 & 8 & Cultural Studies & 185,691 \\
\hline 4 & Dentistry & 189,176 & 9 & $\begin{array}{l}\text { History } \\
\text { Archeology and }\end{array}$ & 185,05 \\
\hline 5 & Politology & 189,125 & 10 & $\begin{array}{l}\text { Public } \\
\text { Administration }\end{array}$ & 183,804 \\
\hline \hline
\end{tabular}


Compared to last year, the demand for the specialty «Public Administration» increased in the TOP-10.

Thus, there is a steady demand for economic specialties in the market of educational services of Ukraine, especially high demand is observed for the specialty «International Economic Relations».

\section{References:}

1. Zakonodavstvo Ukrajiny (2019). Pro zatverdzhennja pereliku ghaluzej znanj $i$ specialjnostej, za jakymy zdijsnjujetjsja pidghotovka zdobuvachiv vyshhoji osvity: Postanova Kabinetu Ministriv Ukrajiny vid 29 kvitnja 2015 roku \# 266 [On approval of the list of branches of knowledge and specialties for which higher education applicants are trained: Resolution of the Cabinet of Ministers of Ukraine of April 29, 2015 No. 266]. Retrieved from: https://zakon.rada.gov.ua/laws/show/266-2015\%D0\%BF (accessed 10 February 2020).

2. Zakonodavstvo Ukrajiny (2019). Pro vyshhu osvitu: Zakon Ukrajiny vid 01.07.2014 \# 1556-VII (redakcija vid 09.08.2019) [On Higher Education: Law of Ukraine dated 01.07.2014 № 1556-VII (edition of 09.08.2019)]. Retrieved from: https://zakon.rada.gov.ua/laws/show/1556-18 (accessed 10 February 2020).

3. Map of first higher education degrees of European country leaders. Retrieved from: https://www.reddit.com/r/europe/comments/7exmd4/map_of_first_higher_ education_degrees_of_european/ (accessed 10 February 2020).

4. Ministerstvo osvity i nauky Ukrajiny (2019). TOP-10 specialjnostej $z$ najvyshhymy prokhidnymy balamy u 2019 roci [Top 10 specialties with highest passing points in 2019]. Retrieved from: https://mon.gov.ua/ua/news/top-10-specialnostej-znajbilshimi-prohidnimi-balami-2019-roku (accessed 10 February 2020).

\section{PROTEIN CONSUMPTION LIKE A FOOD SECURITY INDEX OF THE COUNTRY}

\section{Natela Kordzaia ${ }^{1}$ \\ Bogdan Iegorov ${ }^{2}$}

DOI: https://doi.org/10.30525/978-9934-588-39-6-49

A global food security problem today is more than ever.

There is no country in the world that is concerned with food security. This includes food products production, their distribution, domestic consumption, imports and exports, etc. However, each country has its own features of

\footnotetext{
${ }^{1}$ Odessa National Academy of Food Technologies, Ukraine

${ }^{2}$ Odessa National Academy of Food Technologies, Ukraine
} 